\title{
CRITICAL DISCOURSE ANALYSIS ON LINGUISTIC IDEOLOGY USED ON BILLBOARDS IN JAKARTA
}

\author{
Dery Rovino ${ }^{1)}$ and Theresia Arianti ${ }^{2) *}$ \\ 1) STKIP Media Nusantara Citra \\ 2) STKIP Media Nusantara Citra
}

Received on 19 July 2021 / Approved on 10 October 2021

\begin{abstract}
Indonesian language has long been officially determined as the national language of Indonesia. However, numerous texts in mass media embed English in the text being delivered. Previous studies have shown that English has long been used in Indonesia's different media and platforms to, one of which, enhance the sense of prestige as well as class of the discourse presented. Though some researchers have conducted studies regarding the surface ideation of advertisements, little is known about the linguistic ideology behind the use of English in those texts, wherein the gap is fulfilled by the present study. This study aimed to analyze the linguistic ideology behind the English used on local billboards, with TACO framework. The findings showed that English is often used on local billboards in plenty of non-normative lexical positioning, unconventional spelling, and preferences in source language over the prescribed Bahasa Indonesia loan words. Study also found different modes of Bahasa Indonesia-English coinage as well as some evidence of disconnect between the Bahasa Indonesia-English use of expressions and the actual sold products. This study believes that these eccentric language pairings between Bahasa Indonesia and English lend themselves into the present ideology of prestige enhancement of the product and service advertised. This ideation is derived from a particular narrative that English is superior towards the national language, Indonesian language. Findings also exhibited that economic and education gaps are two main issues hidden behind the use of English on local billboards.
\end{abstract}

Keywords: Critical Discourse Analysis; TACO analysis; Billboards; Applied Linguistics

\begin{abstract}
ABSTRAK
Bahasa Indonesia telah lama ditetapkan sebagai bahasa resmi Negara Kesatuan Republik Indonesia. Namun, tak dapat dipungkiri bahwa Bahasa Inggris acap kali disisipkan ke dalam wacana di media lokal maupun nasional. Penelitian sebelumnya telah menunjukan bahwa Bahasa Inggris kerap kali dianggap efektif untuk menaikan prestis dari sebuah teks. Walaupun terdapat beberapa penelitian sebelumnya yang telah meneliti penggunaan Bahasa Inggris dalam media lokal, belum banyak yang berfokus pada ideologi kebahasaan yang terkandung di dalam teks-teks tersebut. Inilah celah yang diisi oleh penelitian ini dimana penelitian ini bertujuan untuk menganalis ideologi kebahasaan dalam papan reklame bisnis lokal dengan TACO framework. Hasil menunjukan bahwa Bahasa Inggris kerap dipakai pada papan reklame bisnis lokal dengan terdapatnya posisi leksikal non-normatif, pengejaan yang tidak sesuai konvensi, dan preferensi penggunaan kosa-kata Bahasa Inggris dibanding kata serapan dalam Bahasa Indonesia. Hasil juga menunjukan terdapat beberapa cara penciptaan kosa-kata baru hasil gabungan Bahasa Inggris dan Bahasa Indonesia serta terdapat ketidaksinambungan antara ekspresi Bahasa Inggris-Bahasa Indonesia yang dipakai dengan produk yang dijual. Penggunaan campuran Bahasa Inggris dan Bahasa Indonesia ini dipercaya dapat menaikan gengsi dari produk/jasa yang sedang diiklankan. Hal ini berasal dari narasi yang menyatakan bahwa Bahasa Inggris memiliki posisi yang lebih tinggi dibanding Bahasa Indonesia. Tak hanya itu, hasil juga menunjukan bahwa isu kesenjangan ekonomi dan pendidikan merupakan dua masalah utama yang tersembunyi di balik penggunaan Bahasa Inggris di papan-papan reklame tersebut.
\end{abstract}

Kata Kunci: Analisis Wacana Kritis; analisis TACO; papan reklame; Linguistik Terapan

\footnotetext{
*Author(s) Correspondence:

E-mail: dery.rovino@stkipmnc.ac.id; theresia.arianti@stkipmnc.ac.id
} 


\section{INTRODUCTION}

English words have long been part of Indonesians' lexicon. Many Indonesians believe that English can open the window of cross-cultural communication. However, instead of communicative purpose, most of the times English is used to aim for another purpose outside communication. Previous studies have shown that English has long been utilized as a means to boost businesses in nonEnglish-speaking countries. This shows that communicative function has shifted to economic function.

Despite the fact that English is widely used in Indonesia, it is undeniable that Bahasa Indonesia is the official language of the country. In Indonesia, English is still categorized as Foreign Language since, according to Kachru, English has not been an alternative means of communication amongst Indonesian people (Canagarajah, 2013). This leads to the question to what extent English is used as part of the lexicon of Indonesian people, especially in local businesses.

Previous studies have made an attempt to examine the accuracy of English in retail products (Hartono \& Azman, 2019). Hartono \& Azman (2019) also found that there are inaccuracies in paraphrasing the original text, adjusting the lexical elements, translating the original text, choosing the proper vocabulary, structuring the grammar, placing punctuation and spelling.

Moreover, it is stated that there are more than $25 \%$ of English words found in the national media (Redyanita \& Purwaningrum, 2013), this shows that English is commonly used as a powerful marketing tool.

The study covering the use of English in culinary products along airports (Khasanah et al., 2015) shows that there are some factors that underlie the use of English in the marketing of Indonesian products, which are economy and the sense of professionalism. This finding is then further elaborated in the context of ideological positioning. Agha (2006) stated that there is language disorientation that exists in the society. Some languages have been perceived as more superior towards the others.

Previous studies have contributed to the knowledge of the use of English in advertisements in Indonesia. Despite some inaccuracies in it, English used in Indonesian advertisements can boost the economic superiority of the brand advertised. The limitation of most of the previous studies is that the results and discussions are based on the writers' interpretations, so further research is needed.

It is clear that previous studies have long examined the use of English in Indonesia's mass media, TV, and product labels, but not on billboards for local businesses. This is the gap fulfilled by the current study since it aims to identify the linguistic ideology on billboards for local businesses. This study uses Critical Discourse Analysis Framework by O'Reagan (2006). This framework is used because of its effectiveness in evaluating ideological foundation found in a text.

This study starts with studying the literature, collecting the data, and analyzing them to form the full concept of the analysis.

\section{LITERATURE REVIEW}

According to Silverstein, as cited in Woolard (1992), linguistic ideology refers to a shared point of idea about the concept of language in the world. This particular idea is a byproduct of different superior nations and their covert agendas for power and influence in the sectors of economy, politics, and military. Language has notoriously been used to imbue these messages into different modes of texts. In order to decode these covert agendas embedded within texts, a particular tool is required. This is why TACO framework, which will be explained further in Research Design and Methodology part, is the tool used in this study to analyze the linguistic ideology in the data presented.

As a country with a population of more than 270 million people, it is less likely

\footnotetext{
*Author(s) Correspondence:

E-mail: dery.rovino@stkipmnc.ac.id; theresia.arianti@stkipmnc.ac.id
} 
for Indonesia for not being ethnolinguistically extensive. It is found that there are more than 400 local languages with their own hierarchy (Holmes, 2013) and their own variations (Mistar, 2005), meanwhile Lamb \& Coleman (2008) claimed that there are 737 active languages used in this country. Indonesian language, as the national lingua franca, has undergone a long history before being finalized as the official language of the country. Malayan language was chosen to be the means of communication in Dutch Era since Dutch did not want Indonesians to be exposed to European languages which might lead them to be informed of the outside world (Lamb \& Coleman, 2008). In 1945, Indonesian language was officially legitimized as the official language of Indonesia, which this decision has been written in the constitution (Lauder, 2008). Indonesia is claimed to be a multilingual society since many of its people speak more than two languages, covering ethnic languages, Indonesian language, and foreign languages. This multilingualism is believed to have not been treated properly since more and more people in big cities only use one language, Indonesian language, while many people in villages only use their local languages (Lamb \& Coleman, 2008). This shows that the spread of a language in Indonesia is imbalanced, and this even applies to its own lingua franca, Indonesian language.

With this fact, then, where is English embedded in Indonesian linguistic culture? Lamb \& Coleman (2008) stated that, in Indonesia, English has reached a prestigious status. Nunan (2003) found that the constitutionalizing of English is a common course of event that happens in South East Asian countries since this language is seen as the key element to a successful multicultural communication. Indonesian people seem to agree with this view, in which English is highly required for most of the employment in this country. Due to its economic potential,
Indonesian government decided to insert English into the National Curriculum with the hope that Indonesian students will get the benefit of learning it (Lamb \& Coleman, 2008). However, some parties have delivered their objections to this while still acknowledging the advantage of learning English (Lauder, 2008). Numerous attempts have been made to boost the introduction of local culture, and one of them is by allocating more time at school to introduce students to this. However, it is found that some schools use this allocated time for giving extra English lessons. (Lamb \& Coleman, 2008). Overall, Indonesian people believe that English is their main key to prosperous socio-economic conditions (Lamb \& Coleman, 2008; Lauder, 2008).

It can be concluded that Indonesia is right now at its phase of being fanatic towards English. This phenomenon might be explained with the fact that Indonesians believe that English is in line with the success in economy (O'Regan, 2017). It might be also caused by the fact that English is a global language (Kumaravadivelu, 2003). In other words, this is what is meant by Pierre Bourdieu (1977) as "linguistic capital" (p. 648), which he thinks that English as a language with symbolic power, can most likely give the sense of authoritativeness to the native speakers of it, which then leads them to believe that they have a special right to be trusted, obliged, respected, and specialized (p. 648). Therefore, English has been perceived as a language that can elevate people to step out of their low social status (Billings, 2009; Makoni \& Mashiri, 2006).

This study differs from the previous studies about linguistic analysis since the current study focuses on linguistic ideology for its analysis, implied in the Discourse Analysis framework used.

\footnotetext{
*Author(s) Correspondence:

E-mail: dery.rovino@stkipmnc.ac.id; theresia.arianti@stkipmnc.ac.id
} 
Table 1. State of the art

\begin{tabular}{|c|c|c|}
\hline Title & $\begin{array}{c}\text { Writer, year of published, } \\
\text { journal }\end{array}$ & Gap \\
\hline $\begin{array}{l}\text { Penggunaan ikon bahasa asing } \\
\text { maupun daerah dalam } \\
\text { mengkomunikasikan pekan } \\
\text { reklame produk }\end{array}$ & $\begin{array}{l}\text { (Redyanita \& } \\
\text { Purwaningrum, 2013) Jurnal } \\
\text { Epigram }\end{array}$ & $\begin{array}{l}\text { - This study focuses more } \\
\text { on implicit and explicit } \\
\text { messages in a text. } \\
\text { - This study does not } \\
\text { analyze the linguistic } \\
\text { ideology in the data } \\
\text { collected. } \\
\text { - This study does not use } \\
\text { Critical Discourse } \\
\text { Analysis theory. }\end{array}$ \\
\hline $\begin{array}{l}\text { Product Label Translation in } \\
\text { Indonesian Context: Mistake, } \\
\text { Quality, and Solution. } \\
\text { (Terjemahan Label Produk } \\
\text { dalam Konteks Indonesia: } \\
\text { Kesalahan, Kualitas, dan } \\
\text { Solusi.) }\end{array}$ & $\begin{array}{l}\text { (Hartono \& Azman, 2019) } \\
\text { International Journal of } \\
\text { Innovation, Creativity and } \\
\text { Change }\end{array}$ & $\begin{array}{l}\text {-This study focuses on the } \\
\text { accuracy of language } \\
\text { translation. } \\
\text {-This study focuses on the } \\
\text { analysis of lexical and } \\
\text { syntactic element. } \\
\text {-This study does not use } \\
\text { Critical Discourse } \\
\text { Analysis theory. }\end{array}$ \\
\hline $\begin{array}{l}\text { Fenomena Penggunaan Bahasa } \\
\text { Asing dalam Penamaan Bisnis } \\
\text { Kuliner di Kawasan Soekarno- } \\
\text { Hatta Kota Malang. }\end{array}$ & $\begin{array}{l}\text { (Khasanah dkk., 2015) } \\
\text { Jurnal Lingkar Widyaiswara }\end{array}$ & $\begin{array}{l}\text { - This study focuses more } \\
\text { on the society's } \\
\text { perspective on language } \\
\text { use. }\end{array}$ \\
\hline
\end{tabular}

\section{RESEARCH METHODOLOGY}

This study is a descriptive qualitative study. The underlying framework used is from
Critical Discourse Analysis by O'Regan (2006) which can be generally outlined as explained below:

Table 2.

Critical discourse analysis-Text as a critical object framework, O'Reagan (2006)

\begin{tabular}{l|l|l} 
Levels of Analysis & Definition & Helping Questions
\end{tabular}

\begin{tabular}{|l|l|l|}
\hline Descriptive Interpretation & $\begin{array}{l}\text { How the preferred reading is; who the } \\
\text { preferred readers are }\end{array}$ & $\begin{array}{l}\text { How is the frame of the text? How is the } \\
\text { macro genre? Micro genre? Topic } \\
\text { presentation? Implicit message and } \\
\text { audience? }\end{array}$ \\
\hline Representative Interpretation & $\begin{array}{l}\text { What social values can be directed to } \\
\text { the text }\end{array}$ & Picture? Vocabulary? Structure? Genre? \\
\hline Social Interpretation & The social context of the text & $\begin{array}{l}\text { What social context is associated with } \\
\text { the text (gender, race, economy, } \\
\text { business, politics, family, social class, } \\
\text { income, age, property, geography)? }\end{array}$ \\
\hline Deconstructive Interpretation & $\begin{array}{l}\text { The aspects from descriptive, } \\
\text { representative, and social } \\
\text { interpretations which contradict the } \\
\text { preferred reading }\end{array}$ & $\begin{array}{l}\text { What are the aspects from descriptive, } \\
\text { representative, and social interpretations } \\
\text { that contradict the preferred reading? }\end{array}$ \\
\hline
\end{tabular}

According to O'Reagan (2006), Text As a Cultural Object, from which Text As A Critical Object is derived, views a text as a tool to collect cultural and ideological values about a society. This is highly suitable with the purpose of this study which is to examine the linguistic ideology on billboards. TACO (Text As A Critical Object) framework covers four

*Author(s) Correspondence:

E-mail: dery.rovino@stkipmnc.ac.id; theresia.arianti@stkipmnc.ac.id 
linguistic concepts which are descriptive, representative, social and deconstructive interpretations. According to O'Reagan (2006), descriptive interpretation is related to the global outline of the text, which includes the overall layout, preferred reading, and targeted reader. Representative interpretation covers the areas of the inside content of the text, which includes the image, structure, vocabulary and genre. Social interpretation deals with the connection between the text and the social values it contains. While deconstructive interpretation focuses on the link between the text and the elements found in the descriptive, representative and social interpretations.

In this study, the data gathered are thirty samples of local billboards advertising local businesses ranging from food and beverages, property, automotive, electronics and grocery store, as well as beauty and massage salon. Thirty samples are considered suitable for the length of time the researcher has to analyze them. Local businesses are chosen to represent the influence of English in the advertisements that are basically supposed to be in Bahasa Indonesia, since they advertise local products. The samples are gathered by taking pictures on the advertisement billboards around Jakarta and store them in one folder before they are transcribed. Microsoft Excel is then used to code the data. The English element in each transcription is analyzed and the ones having the similar pattern are marked with the same colour. Each type of the English element is given a label. The Excel analysis is then moved into descriptions based on the four elements of TACO framework previously explained. Each TACO sub-title (Descriptive, Representative, Social and Deconstructive Interpretations) is written to be the heading in the Results and Discussion section. Each data analysis is then written under the appropriate heading.

All the samples are qualified for a descriptive study which is aimed to see the dynamic pattern of a text (Dörnyei, 2007).

\section{RESULTS AND DISCUSSION}

The results of this study are based on four components of TACO framework, which are Descriptive Interpretation, Representative Interpretation, Social Interpretation, and Deconstructive Interpretation.

1. Descriptive Interpretation

a. Frame

From 30 samples gathered in the database, the billboard which has the longest writing is the one for catering business (27 words): Catering Jakarta, Catering Jakarta siap melayani Catering sistem pesan Antar ke Gedung Perkantoran, Rumah, pabrik di Jakarta. Juga melayani catering Prasmanan serta menu pondokan untuk Catering Pernikahan. While the shortest one is for the minimart business (2 words only): $\boldsymbol{A l}$ multazam Mart

The average length of writing on the billboards ranges from 10-15 words. The main aim of each billboard is to inform people about the business being advertised, and further, to persuade people to buy/use the product/service written on the billboard. The businesses being advertised include: automotive (7), job advertisement (6), food and beverages (6), stationary (2), property and facility (2), beauty (2), iron selling (2), shoe cleaning (1), education institution (1), and electronic products (1).

\section{b. Genre}

Informative and persuasive are two genres contained in the data. Informative genre is represented by billboards which contain only the names of the businesses, which are: RESTAURANT SULAIMAN and warung nasi d'jawa, while persuasive genre is shown by billboards which advertise the products/services offered by the businesses and persuade people to buy/use the products/services mentioned, as shown here: Dina Salon \& Spa, Creambath tradisional, Cuci blow biasa, cuci blow variasi, cuci blow catok, make up, menicure pedicure, facial tradisional, massage body and Catering Jakarta, Catering Jakarta siap melayani

\footnotetext{
*Author(s) Correspondence:

E-mail: dery.rovino@stkipmnc.ac.id; theresia.arianti@stkipmnc.ac.id
} 
Catering sistem pesan Antar ke Gedung Perkantoran, Rumah, pabrik di Jakarta. Juga melayani catering Prasmanan serta menu pondokan untuk Catering Pernikahan.

Persuasive genre is also shown on the billboards which post job advertisements, in which the writing there persuades job seekers to apply for the job. The two examples are: $\boldsymbol{W e}$ are Hiring; WAITER/SS, COOK WESTERN, COOK HELPER, WESTERN BARTENDER/SS, STEWARD and WALK IN INTERVIEW; CREW RESTAURANT; SENIN, SELASA, RABU $(24,25,26$ Februari 2020). c. Topic Presentation

As has been stated before, topics raised on the billboards include: automotive, job advertisements, food and beverages, stationery, property and facility, beauty, iron selling, shoe cleaning, education institution and electronic stuff. From the language style used on the billboards, it can be concluded that the billboards are written in an informal style. It can be seen from the Indonesian language used on the billboards. The Indonesian language used there is not the standardized Indonesian, as shown below:

Table 3.

\begin{tabular}{|l|l|}
\hline Error & Correction \\
\hline mobil bekas berkwalitas & mobil bekas berkualitas \\
\hline jalan jalan ke luar negeri & jalan-jalan ke luar negeri. \\
\hline
\end{tabular}

They also contain some English elements, which some of them, are not also standardized. Below is the further analysis:

Table 4. The use of Indonesian word formation with English elements

\begin{tabular}{|l|l|}
\hline Error & Correction \\
\hline service ac & AC service \\
\hline bidang study & Study course \\
\hline pulsa electric & Electric balance \\
\hline specialist body repair & Body-repair specialist \\
\hline claim asuransi & Insurance claim \\
\hline marketing property & Property marketing \\
\hline product exclusive & Exclusive product \\
\hline gudang electronic & Electronic warehouse \\
\hline Creambath tradisional & Traditional creambath \\
\hline facial tradisional & Traditional facial \\
\hline massage body & Body massage \\
\hline CREW RESTAURANT & Restaurant crew \\
\hline RESTAURANT SULAIMAN & Sulaiman Restaurant \\
\hline Staff Gudang & Warehouse staff \\
\hline COOK WESTERN & Western cook \\
\hline
\end{tabular}

The words/phrases written above are written in Indonesian formation but with English words, wherein this study coins as a series of non-normative lexical positioning. In Indonesian, the main noun of a noun phrase is put in the initial position, such as 'murid sekolah' and 'guru SD'. In English, those words will be translated into 'school student' and 'primary-school teacher', respectively. It is clear that in English, the main noun of a noun phrase is put in the final position. From the data above, it can be seen that the formation used in the writing is the Indonesian formation (main noun in the initial position), but with the use of English words.

*Author(s) Correspondence:

E-mail: dery.rovino@stkipmnc.ac.id; theresia.arianti@stkipmnc.ac.id 
Table 5. Unconventional spelling

\begin{tabular}{|l|l|}
\hline Error & Correction \\
\hline power stering & power steering \\
\hline kable & cable \\
\hline consultan & consultant \\
\hline salery & salary \\
\hline cleanning & cleaning \\
\hline vacum & vacuum \\
\hline amper & ampere \\
\hline servise & service \\
\hline scapolding & scaffolding \\
\hline flexsibel & flexible \\
\hline menicure & manicure \\
\hline Waitres & waitress \\
\hline Capuccino & Cappuccino \\
\hline
\end{tabular}

The above data show the use of English words with incorrect spelling, as shown on the left. The inaccuracies are influenced by the writing of those words using the phonological sounds. For example, service is pronounced /s3 . . vis/ with $/ \mathrm{s} /$ as the final sound. In Indonesian, the sound $/ \mathrm{s} /$ is written as 's', not ' $c$ '. This might be a great factor why the spelling of 'service' on the billboard is 'servise'. Another example is 'cable'. The word 'cable' is pronounced / ker.bəl/ with $/ \mathrm{k} /$ as the initial sound. In Indonesian, $/ \mathrm{k} /$ sound is written as ' $\mathrm{k}$ ', not ' $\mathrm{c}$ '. It can be concluded that the difference between English as a nonphonetic language and Indonesian as a phonetic language is the source of inaccuracy in the spelling found on the billboards. This somewhat of eccentric spelling convention is what this study refers to as the unconventional spelling.

Table 6. English translation

\begin{tabular}{|l|}
\hline \multicolumn{1}{|c|}{ English Translation } \\
\hline Cash \\
\hline walk-in interview \\
\hline trip - bonus \\
\hline print \\
\hline second \\
\hline ice tea: 4000, milk tea: 5000, lemon tea: 5000 \\
\hline steam \\
\hline starter - electro \\
\hline stamper crane \\
\hline Rental \\
\hline WAITER/SS \\
\hline COOK HELPER \\
\hline WESTERN BARTENDER/SS \\
\hline STEWARD \\
\hline Crew \\
\hline Cleaning Service \\
\hline Black \\
\hline
\end{tabular}

From the above examples, it can be seen that, there are plenty of English translations contained on the billboards. Some of the English translations mentioned are far

*Author(s) Correspondence:

E-mail: dery.rovino@stkipmnc.ac.id; theresia.arianti@stkipmnc.ac.id 
more common to be found than the Indonesian words. 'Cleaning service' is used more than 'petugas kebersihan'; 'interview' has more frequent use than 'wawancara'; 'print' is almost always used to refer to 'cetak', and 'cash' is always preferred compared to 'tunai'.

Table 7. Loan words exist but English is preferred

\begin{tabular}{|l|l|}
\hline \multicolumn{1}{|c|}{ English word } & \multicolumn{1}{c|}{ Indonesian loan word } \\
\hline foto copy & fotokopi \\
\hline laminating & laminasi \\
\hline fax & Faksimili \\
\hline exclusive & eksklusif \\
\hline design & desain \\
\hline service & servis \\
\hline Catering & katering \\
\hline Capuccino & kapucino \\
\hline
\end{tabular}

The above data show that each English word has its loan word in Indonesian, however, the English word is preferred. Most Indonesians are far more familiar with the English version compared to the Indonesian one. This might influence the business owner to choose the English word since 'languagestyle' familiarity will highly affect people's decision whether or not to read the billboards.

Table 8. English phrase

\begin{tabular}{|l|}
\hline \multicolumn{1}{|c|}{ English Phrase } \\
\hline swimming pool specialist \\
\hline build \& treatment \\
\hline full body \\
\hline daily shoes cleaning service \\
\hline
\end{tabular}

In addition to English words, English phrases are also used on the billboards. Some of these English phrases are very common to use in Indonesia to the extent that the Indonesian version is rarely even heard of.

Table 9. Grammar issue

\begin{tabular}{|l|l|}
\hline \multicolumn{1}{|c|}{ Error } & \multicolumn{1}{c|}{ Correction } \\
\hline 2 phaase -3 phase & 2 phases-3 phases \\
\hline
\end{tabular}

There is only one grammar issue found on the overall billboards. It shows that grammar is not a huge problem in the use of English on Indonesian billboards.

\section{d. Preferred Reading and Preferred Reader}

All of the billboards have one main purpose which is to inform and persuade people to buy/use the products/services mentioned. It can be undoubtedly said that the business owner wishes that readers will become familiar on their business by reading the billboard placed, and therefore, they will buy/use the products/services being advertised, eventually. The targeted readers are any passersby who happen to cross in front of the billboards. The inclusion of English elements is believed to be an effective tool to enhance the prestige of the business being advertised since English is commonly valued as more

*Author(s) Correspondence:

E-mail: dery.rovino@stkipmnc.ac.id; theresia.arianti@stkipmnc.ac.id 
prestigious than Indonesian language. As stated by Kachru and Martin (as cited in Da Silva, A.M., 2014), English has received a more prestigious label compared to Indonesian and other local languages. The inclusion of English elements in the writing also shows that people from middle-to-high social classes are the target readers since only people from these social classes have access to good education, which also means access to English language learning. Moreover, since the topics contained on the billboards are related to secondary and tertiary needs (private vehicles, beauty treatment, restaurants), it can be concluded that the target readers are passersby coming from middle-to-high social classes. Having middle class as the target readers is believed to be economically advantageous for business owners. As stated by Worldbank (2020), middle class is the main economic power in Indonesia as their consumption is almost half of the overall household consumption in this country.

\section{Representative Interpretation}

\section{- Image}

The writing on the billboards is found to be straightforward. When the business advertised is a food and beverage business, the writing will straightforwardly inform the reader about the menu offered or the name of the restaurant itself; when the billboard shows beauty treatment businesses, the writing will directly mention the types of treatment offered, as can be seen below:

Table 10. Straightforward Message

warung nasi d'jawa

NEW! Djarum Black Capuccino, DJARUM BLACK

Dina Salon \& Spa, Creambath tradisional, Cuci blow biasa, cuci blow variasi, cuci blow catok, make up, menicure pedicure, facial tradisional, massage body,

It is done since, as has been stated before, the target reader is a passerby who happens to cross in front of the billboard. Giving too many irrelevant words is unnecessary since the target reader does not have a sufficient amount of time to read the billboard thoroughly.

The data show the billboards use English elements in advertising the business. It is done to enhance the image of the business being advertised since English is valued as more prestigious than Indonesian language. According to Da Silva (2014), youngsters tend to consider English to be 'cool'. Da Silva (2014) also stated that English advertisements are usually targeted for upper-class markets. This shows that English could bring a positive image, i.e. cool or rich, to the brand advertised. Moreover, some phrases are shorter to be written in English than in Indonesian. It supports the simplicity that the business owner is concerned with, since the

*Author(s) Correspondence:

E-mail: dery.rovino@stkipmnc.ac.id; theresia.arianti@stkipmnc.ac.id target reader does not have a sufficient amount of time to read the writing on the billboard.

- Vocabulary

The vocabulary used on the billboards show the inclusion of English elements. However, most of them contain errors, as explained in Descriptive Interpretation part. The inclusion of English elements in an advertisement is believed to be able to level up the prestige of the business. The topics contained on the billboards are related to middle-to-high social classes since the businesses advertised are related to automotive, food and beverage, and beauty treatment. Indonesia is a developing country where the economic gap is still becoming a main issue. People who have the privilege to own a private vehicle, eat at a restaurant, and do a beauty treatment at a salon are the ones coming from middle-to-high social classes. This is believed to be the reason why the billboards include English elements in the 
advertisements, i.e. to attract people from middle-to-high social classes who mostly have a sufficient amount of English proficiency. However, errors contained in the English elements on the billboards show that the inclusion of English on those billboards has not been done with a sufficient level of accuracy; the accuracy of the English elements seems to be quite neglected. It shows that, as long as there are English elements in the advertisements, people will feel that the products/services are prestigious, regardless of the accuracy of the English elements used.

\section{- Grammar}

Since the billboards are written in Indonesian, there is no English grammar used except for one sentence in Present Continuous (We are hiring). Present continuous is used to show that the recruitment process is ongoing. This delivers the message of 'urgency' for job seekers looking for employment.

\section{Social Interpretation}

- Social Framework Constituents

The inclusion of English elements, irrespective of the accuracy, is believed to be able to level up the prestige of the business being advertised. This shows that there is a sense of inferiority to fully use Indonesian in the advertisements. On the other hand, there is a sense of superiority to include English in the advertisements. This is closely related to linguistic imperialism. According to Phillipson (2018), the great power of English in Asia is the result of past colonization. This has caused English to gain the predicate of 'prestigious' in Asian countries, including Indonesia. This is supported by the results of previous studies which show that English is viewed as superior compared to national/local languages.

\section{- Further Social Issue}

Since the advertisements are about secondary and tertiary needs (automotive, food and beverages, beauty treatment), it is believed that the target readers are people from middleto-high social classes. This pool of people commonly has adequate levels of education, which means they have sufficient knowledge of English. This might be a strong reason why business owners prefer to include English elements into their advertisements, i.e. to show prestige. On the other hand, people from lower socio-economic class rarely own the privilege of having good education, which then results in the insufficient knowledge of English these people have. This shows the economic gap existing in this country and the education problem that entails it.

\section{Deconstructive Interpretation}

The preferred reading of the advertisements is to inform and persuade readers regarding the businesses being advertised. Through the analysis done in descriptive, representative, and social interpretations, it can be concluded that this preferred reading is mostly achieved. The types of business (secondary and tertiary products) are in line with the target readers (people from middle to high social classes). These are also in line with the inclusion of English elements to increase the prestige of the products being advertised, as 'English' and 'prestige' are closely related to middle-to-high social classes.

However, the errors found in the English used on the billboards degrade the achievability of the preferred reading. Instead of creating a sense of prestige to the products mentioned, the errors might somehow lead to a sense of silliness for the target readers. Considering that the target readers will be the ones who have a sufficient level of education, it is disadvantageous for the business owners to promote their products with 'inaccurate' English.

\section{CONCLUSION}

Based on the descriptive, representative, social, and deconstructive analyses conducted to figure out the linguistic ideology contained on the billboards, it can be concluded that billboards advertising secondary and tertiary businesses in Jakarta use English elements that are recurrently used on local billboards in plenty of non-normative

\footnotetext{
*Author(s) Correspondence:

E-mail: dery.rovino@stkipmnc.ac.id; theresia.arianti@stkipmnc.ac.id
} 
lexical positioning, unconventional spelling, and preferences in source language over the prescribed Bahasa Indonesia loan words. Study also found different modes of Bahasa Indonesia-English coinage as well as some evidence of disconnect between the Bahasa Indonesia-English use of expressions and the actual sold products. This study believes that these eccentric language pairings between Bahasa Indonesia and English lend themselves into the present ideology of prestige enhancement of the product and service advertised.

The literature points to a narrative that these linguistic acts were performed to level up the prestige of the products/services advertised. The findings suggested that English is devised in order to meet the standard of the targeted readers, people from middle to high social classes. The selection of these target readers is also seen to be beneficial since middle class is the main source of consumption in Indonesia. However, careful control should be put into serious consideration in order to avoid inaccuracies in the English used on those billboards. Economic gap, which leads to education gap, is another social issue represented in the use of English on billboards in Jakarta. It is suggested that future studies examine this same topic in other cities in Indonesia to see the overall trend of English use on billboards at the national level.

\section{REFERENCES}

Agha, A. (2006). Language and social relations. In Language and Social Relations.

https://doi.org/10.1017/CBO97805116 18284

Billings, S. (2009). Speaking beauties: Linguistic posturing, language inequality, and the construction of a Tanzanian beauty queen. Language in Society, 38(5), 581-606. https://doi.org/10.1017/S00474045099 90443
Bourdieu, P. (1977). The economics of linguistic exchanges. Theories and Methods, 645-668.

Canagarajah, S. (2013). Translingual Practice: Global Englishes and Cosmopolitan Relations (1 ed.). Routledge, Taylor and Francis Group. http://www.tandfebooks.com/ISBN/97 80203073889

Dörnyei, Z. (2007). Research methods in Applied Linguistics. Oxford University Press.

Hartono, R., \& Azman, M. N. A. (2019). Product Label Translation in Indonesian Context: Mistake, Quality, and Solution. International Journal of Innovation, Creativity and Change, 9(9).

Holmes, J. (2013). An Introduction to Sociolinguistics (4 ed.). Routledge, Taylor and Francis Group.

Khasanah, I., Dwita, L., Rosa, D. C. T., \& Roy, R. A. (2015). Fenomena Penggunaan Bahasa Asing dalam Penamaan Bisnis Kuliner di Kawasan Soekarno-Hatta Kota Malang. Jurnal Lingkar Widyaiswara. Edisi, 2.

Kumaravadivelu, B. (2003). Critical language pedagogy: A Postmethod Perspective on English Language Teaching. World Englishes, 22(4), 539-550. https://doi.org/10.1111/j.1467971X.2003.00317.x

Lamb, M., \& Coleman, H. (2008). Literacy in English and the transformation of self and society in post-Soeharto Indonesia. International Journal of Bilingual Education and Bilingualism, 11(2), 189-205. https://doi.org/10.2167/beb493.0

Lauder, A. (2008). The Status and Function of English in Indonesia: A Review of Key Factors. Makara, Sosial Humaniora, 12(1), 9-20. http://journal.ui.ac.id/index.php/human ities/article/viewFile/128/124

Makoni, S., \& Mashiri, P. (2006). Critical Historiography: Does Language Planning in Africa Need a Construct of Language as Part of its Theoretical

*Author(s) Correspondence:

E-mail: dery.rovino@stkipmnc.ac.id; theresia.arianti@stkipmnc.ac.id 
Apparatus? Disinventing and

Reconstituting Languages, September, 62-89.

Mistar, J. (2005). Teaching English as a foreign language (TEFL) in Indonesia. In G. Braine (Ed.), Teaching English to the World: History, curriculum and practice (hal. 71-80). Lawrence Erlbaum Associates. https://doi.org/10.4324/978141061286 1

Nunan, D. (2003). The Impact of English as a Global Language on Educational Policies and Practices in the Asia-Pacific Region*. Tesol Quarterly, 37(4), 589-613. https://doi.org/10.2307/3588214

O'Regan, J. (2017). The future of Englishes (hal. 1-21). moodle.ucl.ac.uk

O'Regan, J. P. (2006). The text as a critical object: on theorising exegetic procedure in classroom-based critical discourse analysis. In Critical Discourse Studies (Vol. 3, Nomor 2, hal. 179-209). Routledge, Taylor and Francis Group. https://doi.org/10.1080/174059006009 08111

Redyanita, H., \& Purwaningrum, E. (2013). Penggunaan ikon bahasa asing maupun daerah dalam mengkomunikasikan pekan reklame produk. Epigram, 10(1), 75-80.

Marietta, A. (2013). Upon the Prevalence of English on Billboard Advertisements: Analyzing the Role of English In Indonesian Contexts 1, 33-61.

Phillipson, R. (2018). Linguistic Imperialism. https://doi.org/10.1002/978140519843 1.wbeal0718.pub2

Woolard, K. A. (1992). Language ideology. Pragmatics. Quarterly Publication of the International Pragmatics Association (IPrA), 2(3), 235-249. https://doi.org/10.1075/prag.2.3.01 woo

World Bank (2020). Aspiring Indonesia: Expanding the Middle Class.

*Author(s) Correspondence:

E-mail: dery.rovino@stkipmnc.ac.id; theresia.arianti@stkipmnc.ac.id
Retrieved from https://www.worldbank.org/en/country indonesia/publication/aspiringindonesia-expanding-the-middle-class 